Malaysian Journal of Social Sciences and Humanities (MJSSH)

Volume 4, Issue 7, November 2019

e-ISSN : 2504-8562

Journal home page:

www.msocialsciences.com

\title{
Faktor-faktor yang Mempengaruhi Komitmen Prestasi Kerja dalam kalangan Penjawat Awam. Kajian Rintis di Jabatan Kemajuan Masyarakat, Negeri Pulau Pinang
}

\author{
Norsyamimi Nordin ${ }^{1}$, Mohammad Mujaheed Hassan ${ }^{1}$ \\ 1Jabatan Sains Kemasyarakatan dan Pembangunan, Fakulti Ekologi Manusia, Universiti Putra Malaysia (UPM) \\ Correspondence: Mohammad Mujaheed Hassan (mujaheed@upm.edu.my)
}

\begin{abstract}
Abstrak
Kualiti modal insan memainkan peranan penting dalam menentukan hala tuju penjawat awam di samping memastikan kecekapan pengurusan. Produktiviti sesebuah organisasi bergantung kepada kualiti prestasi kerja. Keratan akhbar Utusan online bertarikh 22 November 2010 melaporkan jumlah penjawat awam yang bermasalah dan berprestasi rendah meningkat kepada 6,133 orang pada tahun 2009 berbanding 5,344 orang pada tahun 2008. Kajian ini dibuat bertujuan untuk mengkaji faktor yang mempengaruhi komitmen kerja seseorang pekerja terhadap prestasi kerja. Seramai 100 orang kakitangan daripada Jabatan Kemajuan Masyarakat (KEMAS) Negeri Pulau Pinang, Daerah Seberang Perai Tengah telah dijadikan responden. Rekabentuk kajian adalah kajian deskriptif berbentuk tinjauan yang menggunakan borang soal selidik untuk mengumpul data. Borang soal selidik terbahagi kepada tiga bahagian iaitu a) maklumat responden; b) faktor komitmen kerja; dan c) prestasi kerja. Data dianilisis dengan menggunakan perisian Statistical Package for the Social Sciences (SPSS) Version 21 untuk menilai kekerapan, peratusan, purata, ujian korelasi, ujian $t$ dan ujian anova. Hasil kajian menunjukkan tahap prestasi kerja dalam kalangan penjawat awam adalah tinggi dan faktor minat merupakan faktor komitmen kerja utama yang mempengaruhinya. Manakala hubungan antara faktor minat dengan prestasi kerja juga menunjukkan hubungan korelasi yang kuat dengan nilai $\mathrm{r}=0.593$ pada aras $\mathrm{p}<0.05$. Bagi analisis perbezaan prestasi kerja mengikut jantina dan tempoh perkhidmatan, dapatan kajian menunjukkan perbezaan yang signifikan antara prestasi kerja mengikut tempoh perkhidmatan. Tuntasnya, hasil kajian mendapati bahawa inisiatif perlu diambil oleh pihak organisasi bagi memupuk minat para pekerja terhadap pekerjaan yang mereka lakukan.
\end{abstract}

Kata kunci: faktor komitmen kerja, prestasi kerja, minat, penyeliaan, rakan sekerja, pendapatan, perkhidmatan awam

\section{Factors Influencing Work Performance Commitment Among Civil Servant: A Pilot Test in Penang Social Development Department (KEMAS)}

\begin{abstract}
The quality of the nation's human capital plays an important role in determining the direction of civil servants as well as ensuring management efficiency. The productivity of an organisation is dependant on the quality of its workforce. The Utusan Online newspaper dated November 22, 2010 reported that the number of distressed and low-performing civil servants has increased to 6,133 people in 2009 compared to 5,344 in 2008 . This study aims to examine the underlying factors that influence an employee's commitment to work performance. A total of 100 staff from the Community Development
\end{abstract}


Department (KEMAS) of Seberang Perai Tengah District in Penang, participated in this survey. The study design was a descriptive study which used survey forms to collect data. The questionnaire comprised of three sections: a) respondent information; b) factors influencing work commitment; and c) work performance. The data obtained was analysed using the Statistical Package for the Social Sciences (SPSS) Version 21 software in order to evaluate the frequency, percentage, average, correlation test, $t$ test and anova test. The results show that the level of work performance among the civil servants is high and interest in work is the main factor leading to work commitment. While the relationship between work interest and job performance also showed strong correlation with the value of $r=0.593$ at $p<0.05$. For the analysis of differences in work performance by gender and duration of service, the study findings show significant differences between work performance by service period. The implications of the study towards the organisation involved shows that the institution should take initiatives to foster / increase the workers' interest in the work that they do.

Keywords: factors of commitment, job performance, interest, supervision, co-workers, income, civil service

\section{Pengenalan}

Prestasi kerja dilihat sebagai suatu set tingkah laku yang relevan dengan pencapaian matlamat organisasi atau unit organisasi tempat seseorang itu bekerja (Murphy, 1990 dalam Rambli 2001). Neol (2009) pula mendefinisikan prestasi kerja sebagai satu proses dimana pengurus bertanggungjawab memastikan aktiviti dan produktiviti pekerja selari dengan matlamat organisasi. Dalam sektor awam, kerajaan telah menyarankan budaya kerja berasaskan prestasi dengan menggunakan petunjuk-petunjuk prestasi utama atau Key Performance Indicators (KPI) yang diterapkan dalam perkhidmatan awam bagi meningkatkan kualiti penyampaian perkhidmatan. Sejajar dengan visi, misi dan fungsi agensi, setiap organisasi perlu mengukur prestasi perkhidmatan yang diberikan bagi memastikan semua perkhidmatan berkenaan disampaikan kepada pelanggan dengan baik. Ini secara tidak langsung dapat memberikan gambaran yang jelas mengenai prestasi organisasi secara keseluruhannya.

Petunjuk-petunjuk prestasi utama atau Key Performance Indicators (KPI) adalah satu sistem pengukuran yang mudah, berkesan dan membantu organisasi menjelaskan dan mengawal tahap kemajuan sesuatu proses perkhidmatan yang disampaikan kepada pelanggan selaras dengan misi dan visi sesebuah organisasi (Pekeliling Kemajuan Pentadbiran Awam Bilangan 2 Tahun 2005). Prinsipprinsip KPI ialah meletakkan sasaran, boleh diukur dengan angka, diukur dalam keadaan normal dan selaras dengan misi dan visi organisasi. KPI adalah ukuran spesifik dalam bidang tertentu prestasi organisasi.

Keratan akhbar Harian Metro online bertarikh 03 Disember 2015 melaporkan seramai 2,943 penjawat awam kini berada dalam 'radar' kerajaan selepas mereka masing-masing mencatatkan prestasi kerja rendah di bawah 60 markah sepanjang tempoh penilaian tahun lalu. Berdasarkan laporan dalam akhbarakhbar yang dinyatakan tersebut, masalah prestasi kerja dalam kalangan penjawat awam semakin membimbangkan walaupun kerajaan telah bertungkus lumus melaksanakan pelbagai transformasi dan pembaharuan dalam perkhidmatan awam. Isu seperti ini akan menjejaskan imej perkhidmatan awam di negara kita dan menimbulkan persoalan mengenai kualiti kerja penjawat awam. Presiden Kongres Kesatuan Pekerja-pekerja dalam Perkhidmatan Awam (CUEPACS) iaitu Datuk Azih Muda yang dilaporkan dalam Utusan online bertarikh 03 Disember 2015 menyatakan bahawa beliau bersetuju dengan tindakan terhadap penjawat awam yang menunjukkan prestasi kerja tidak memuaskan dikenakan pemberhentian kerja. Menurut beliau lagi, CUEPACS menyokong langkah kerajaan itu dalam usaha untuk mempertingkatkan mutu perkhidmatan awam serta memberi pengajaran kepada mereka untuk lebih mengekalkan tahap integriti yang baik dalam melaksanakan tugas. 


\section{Objektif Kajian}

Menyedari akan kepentingan prestasi kerja dalam meningkatkan kecemerlangan sesebuah organisasi, maka kajian ini ingin mengkaji faktor komitmen kerja mempengaruhi prestasi kerja dalam kalangan penjawat awam khususnya di Jabatan Kemajuan Masyarakat Negeri Pulau Pinang, Daerah Seberang Perai Tengah.

\section{Kajian Lepas}

Dalam kajian "Perkaitan kepuasan kerja dengan prestasi kerja di kalangan pekerja di industri pembuatan" oleh Rambli bin Haji Hasbi pada tahun 2001, beberapa indikator sebagai petanda ukuran prestasi seseorang pekerja telah dikenalpasti antaranya tahap kehadiran kerja, ketepatan waktu bertugas, disiplin semasa kerja, kuantiti kerja, kualiti kerja dan sikap bekerjasama. Walaubagaimanapun, bagi pekerja sektor awam khususnya, berdasarkan kepada Laporan Nilaian Prestasi Tahunan (LNPT) yang diperoleh daripada Jabatan Perkhidmatan Awam (JPA), antara aspek yang diambil kira bagi mengukur prestasi para pekerjanya adalah penghasilan kerja, pengetahuan dan kemahiran, kualiti peribadi, jalinan hubungan dan kerjasama serta kegiatan dan sumbangan.

Berdasarkan kepada kajian oleh Che Mohd Syaharuddin Che Cob, Bahyah Abdul Halim dan Aziz Amin (2017) yang bertajuk "Faktor-faktor yang mempengaruhi prestasi kerja dalam kalangan penjawat awam: satu kajian teoritikal", dapatan kajian tersebut membuktikan bahawa dalam meningkatkan prestasi kerja, faktor individu iaitu ciri-ciri personaliti, motivasi, autonomi pembelajaran dan faktor kumpulan iaitu gaya kepimpinan ketua amat penting dalam mempengaruhi pelbagai aspek keberkesanan prestasi kerja. Di samping itu, menurut Noralai dan Norhasni (2010) dalam kajiannya "Tinjauan faktor-faktor yang mempengaruhi komitmen pekerja terhadap organisasi", secara amnya, terdapat beberapa faktor yang dominan yang mempengaruhi komitmen prestasi pekerja iaitu faktor penyelia, rakan sekerja, pendapatan dan minat terhadap pekerjaan.

Penyeliaan yang baik melibatkan aktiviti memberi bimbingan, mengarah dan memberitahu apa yang patut dibuat, bukannya mencari kesalahan. Glickman dan Gordon (1995) telah meletakkan penyeliaan sebagai tulang belakang keberkesanan sesebuah organisasi. Penyeliaan yang berkesan memerlukan perancangan yang baik dan dilaksanakan secara berterusan untuk memastikan matlamat dan objektif pengajaran yang dijalankan oleh seseorang individu itu tercapai. Morgan (1978) menyatakan bahawa pengaruh penyelia amat penting ke atas komitmen seseorang pekerja. Conrad (1985) pula mengandaikan bahawa penyeliaan yang berorientasikan hubungan manusia akan meningkatkan komitmen kerja kerana ianya dapat memenuhi keperluan bukan ekonomi pekerja. Galakan daripada penyelia merupakan salah satu faktor penting yang mempengaruhi komitmen pekerja. Zeichner (1983) berpendapat bahawa penyelia sangat mempengaruhi cara seseorang itu bekerja. Hal ini adalah kerana penyelia terlibat secara langsung dalam penilaian prestasi kerja dimana penilaian ini adalah berdasarkan komitmen yang ditunjukkan oleh pekerja semasa menjalankan tugas mereka. Oleh itu, seseorang penyelia bertanggungjawab memberi bimbingan, tunjuk ajar, sokongan, mendengar masalah dan memberi perhatian yang sewajarnya kepada para pekerja.

Farrel (2003) menyatakan bahawa pekerja yang baru memerlukan bantuan dan sokongan daripada rakan sekerja sejak mereka mula-mula menceburi bidang pekerjaan mereka. Sokongan rakan sekerja adalah penting dalam perkembangan kerjaya dan proses sosialisasi. Hal ini kerana rakan sekerja merupakan panduan dan penunjuk ajar paling terdekat dengan pekerja baru (Zeichner, 1983). Walaupun rakan sekerja tidak mempunyai kuasa seperti penyelia untuk mempengaruhi pekerja baru ini, tetapi ianya boleh mempengaruhi pekerja terutama yang baru menceburi sesuatu pekerjaan secara tidak formal (Jordell, 1987). Cole (1991) telah menggesa agar pekerja dapat mencari peluang untuk berinteraksi dan membina hubungan dengan rakan sekerja yang lain yang boleh dipercayai. Hal ini kerana pekerja melalui pelbagai tahap perkembangan seperti perkembangan dari aspek sosialisasi dan profesionalisme. 
Dalam satu kajian yang dilaksanakan oleh Goldthorpe (1968) terhadap pekerja berbangsa British yang dibayar gaji tinggi, mendapati responden menunjukkan tahap kepuasan kerja yang tinggi walaupun kerja-kerja yang mereka lakukan amat membosankan, instrumentatif dan kurang ganjaran-ganjaran dalaman. Ganjaran selalu dikaitkan dengan profesionalisme sesuatu kerja. Semakin tinggi tahap profesionalisme sesuatu tugas, semakin tinggi gaji dan ganjaran yang diterima (Hodson dan Sullivan, 1995).

Hilgard (1995) menyatakan "interest is persisting tendency to pay attention to end enjoy some activity and content." Menurut beliau, minat adalah keinginan untuk melakukan sesuatu kegiatan dalam mencapai sesuatu tujuan. Semakin tinggi keinginan seseorang untuk mencapai matlamat, semakin kuat minat yang mendorong mereka. Tambahan pula, Sardiman (2000) menjelaskan bahawa minat merupakan suatu keadaan yang terjadi apabila seseorang itu melihat ciri-ciri atau situasi yang dihubungkan dengan keinginan dan kebolehannya sendiri. Minat memainkan peranan yang penting dalam membentuk keberhasilan kerja seseorang. Minat merupakan faktor dalaman dalam diri seseorang dimana ianya juga dapat menentukan pemikiran seseorang. Seseorang yang melakukan pekerjaan yang disertai dengan minat, pada umumnya akan memperoleh hasil yang lebih baik daripada mereka yang melakukan sesuatu pekerjaan tidak disertai dengan minat.

Minat wujud disebabkan oleh daya tarikan daripada luar mahupun yang datang daripada hati sanubari seseorang itu. Minat yang besar terhadap sesuatu merupakan aspek utama untuk mencapai atau memperoleh hasil atau matlamat yang diminatinya itu (Dalyono, 1997). Dalam usaha untuk memperolehkan sesuatu, faktor minat amat penting. Besar atau kecil minat yang dimiliki akan mempengaruhi hasil yang diperoleh. Minat wujud dengan adanya kesedaran, ilmu pengetahuan atau maklumat mengenai sesuatu objek tertentu. Minat tidak diperoleh sejak lahir kerana minat wujud melalui apa yang dipelajari dan ianya mempegaruhi proses selanjutnya. Seseorang yang memiliki minat terhadap sesuatu jenis pekerjaan tertentu akan melakukan langkah-langkah nyata untuk mengetahui segala sesuatu tentang pekerjaan yang diminatinya.

Menurut Le Thi (2007), faktor yang amat penting dalam mencari kesesuaian minat dan prestasi kerja adalah dengan menempatkan seseorang individu itu di tempat kerja yang berpadanan dengannya. Manakala dari aspek kepuasan yang dicapai pula, ianya terhasil daripada kebolehan dan keupayaan yang ditunjukkan dalam pekerjaan. Kepuasan diri dapat dicapai hasil daripada keupayaan seseorang individu dalam menunjukkan minat terhadap sesuatu kerjaya. Minat terhadap pekerjaan itu sendiri merupakan salah satu daripada faktor persekitaran tempat kerja yang mempengaruhi komitmen. Oleh itu, organisasi perlu memberi galakkan, merancang latihan dan kursus, menetapkan jangka masa untuk menyiapkan kerja dan memberi semangat kepada pekerja supaya dapat memberikan komitmen yang lebih tinggi dalam pekerjaan mereka. Menurut Conrad (1985), tahap sumbangan dan komitmen kerja yang dihasilkan oleh pekerja adalah bergantung kepada sejauhmana pekerja berpuashati dengan layanan yang diberi oleh pihak pengurusan. Pendapat ini selari dengan pernyataan yang diberikan oleh Bendix (1956) yang berpendapat bahawa kegagalan pihak pengurusan memberi layanan yang baik dan menganggap pekerja sebagai manusia boleh menyebabkan moral pekerja rendah, hasil kerja rendah dan tiada maklum balas daripada pekerja.

\section{Kerangka Konseptual}

Menurut Mottaz (1988), komitmen ialah sebagai hasil tindak balas afektif daripada penilaian individu terhadap kerjanya yang mungkin boleh mengikat individu dengan institusi atau organisasi. Menurut Mottaz lagi, individu menyertai organisasi untuk membolehkannya menggunakan kemahiran, memenuhi keinginan dan mencapai matlamat individu. Sekiranya organisasi tidak dapat memberikan peluang untuk individu itu, peluang untuk mencapai kehendak dan matlamat, maka komitmen individu akan lenyap. Dalam konteks kajian ini, komitmen kerja dilihat sebagai usaha, kerja keras dan kesukarelaan pekerja untuk menyumbang kepada matlamat organisasi. Dalam kajian ini, empat faktor komitmen kerja yang dikatakan paling terdekat dengan seseorang individu adalah i) Faktor Penyeliaan, ii) Faktor Rakan Sebaya, iii) Faktor Pendapatan dan iv) Faktor Minat. 
Prestasi kerja merujuk kepada tingkah laku atau sikap yang menunjukkan seseorang itu berhubungan dengan pekerjaannya dan kebiasannya merujuk kepada tindakan dan tingkah laku di bawah kawalan seseorang individu yang menyumbang kepada matlamat organisasi (Rotundo dan Sackett, 2002). Dalam konteks kajian ini, prestasi kerja merujuk kepada hasil kerja yang telah dicapai oleh seseorang dalam melaksanakan tugas-tugas yang dibebankan kepadanya. Prestasi kerja penjawat awam diukur berdasarkan kepada aspek-aspek seperti kebolehan menguruskan sumber, jalinan hubungan dan kerjasama, keberkesanan komunikasi, disiplin kerja, komitmen terhadap pekerjaan, kualiti dan kuantiti produk dan orientasi pencapaian. Penyelidik telah menggunakan borang soal selidik yang diadaptasi daripada Aznira Binti Zakaria (2014) untuk mengukur prestasi kerja berdasarkan aspek-aspek tersebut.

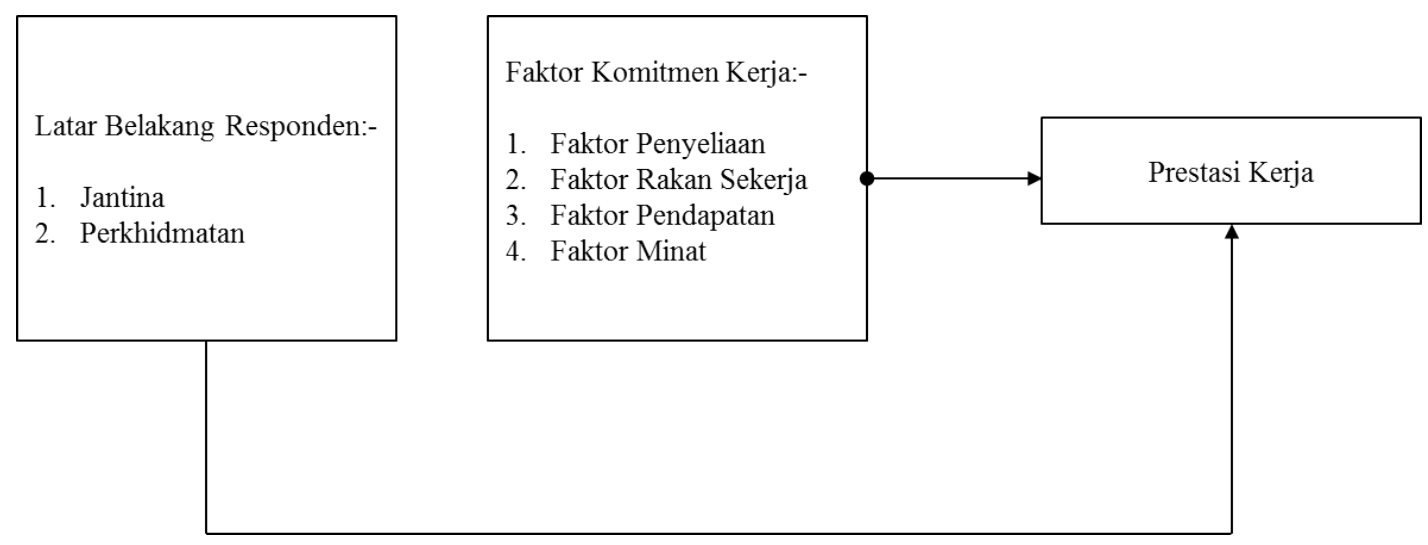

Rajah 1 : Kerangka konseptual Faktor Komitmen Kerja kepada Presatsi Kerja

\section{Metod Kajian}

Kajian ini bertujuan mengkaji faktor komitmen kerja mempengaruhi prestasi kerja dalam kalangan penjawat awam. Kajian ini dijalankan di Jabatan Kemajuan Masyarakat (KEMAS) Negeri Pulau Pinang, Daerah Seberang Perai Tengah. KEMAS Daerah Seberang Perai Tengah mempunyai tiga (3) parlimen di bawahnya iaitu parlimen kawasan Batu Kawan, parlimen kawasan Permatang Pauh dan parlimen kawasan Bukit Mertajam. Populasi sasaran penyelidik dalam kajian ini terdiri daripada kakitangan awam di Jabatan Kemajuan Masyarakat (KEMAS) Negeri Pulau Pinang, Daerah Seberang Perai Tengah yang berjumlah seramai 100 orang kakitangan iaitu dengan pecahaan mengikut parlimen:- i) Parlimen Batu Kawan 30 orang; ii) Parlimen Permatang Pauh 40 orang dan iii) Parlimen Bukit Mertajam 30 orang. Pemilihan lokasi ini adalah kerana menurut keratan akhbar Kosmo bertarikh 21 September 2016 yang bertajuk "Tabika KEMAS miliki kualiti tinggi" melaporkan bahawa pusat pendidikan awal yang dikendalikan oleh KEMAS mempunyai kualiti jauh lebih baik berbanding daripada tadika swasta. Oleh itu, lokasi ini amat bersessuaian untuk di jadikan sebagai kajian rintis untuk mengkaji faktor yang mempengrauhi komitmen prestasi kerja seseorang.

Pembolehubah tidak bersandar yang akan diukur adalah faktor komitmen kerja yang merangkumi i) faktor penyeliaan, ii) faktor rakan sebaya, iii) faktor pendapatan dan iv) faktor minat manakala pembolehubah yang bersandar adalah prestasi kerja.

Instrumen pengumpulan data adalah dalam bentuk edaran kajian borang soal selidik. Terdapat tiga bahagian di dalam set borang soal selidik iaitu Bahagian A, B dan C. Bahagian A mengandungi soalasoalan berkaitan dengan maklumat responden seperti jantina, umur dan tempoh perkhidmatan. Seterusnya Bahagian B mengandungi soalan-soalan berkaitan dengan faktor-faktor komitmen kerja iaitu faktor penyelia, faktor rakan sekerja, faktor pendapatan dan faktor minat. Akhir sekali Bahagian C mengandungi soalan-soalan berkaitan dengan prestasi kerja. Kajian ini berbentuk kauntitatif dengan menggunakan emapt skala likert iaitu $1=$ sangat tidak setuju, $2=$ tidak setuju, $3=$ setuju, dan $4=$ sangat setuju. Responden akan memilih salah satu daripada jenis skala tersebut. Data yang diperolehi dianalisis menggunakan analisis deskrptif dan analisis korelasi pearson. 


\section{Hasil Kajian \& Perbincangan}

\section{Analisis Faktor Komitmen Kerja Utama yang mempengaruhi Prestasi Kerja}

Hasil kajian mendapati bahawa faktor minat merupakan faktor utama yang mempengaruhi komitmen prestasi kerja penjawat awam KEMAS, Daerah Seberang Perai Tengah dengan skor mean tertinggi iaitu 2.7694 (Jadual 1).

Jadual 1 : Skor Mean bagi setiap Faktor Komitment Kerja

\begin{tabular}{lc}
\hline \multicolumn{1}{c}{ Faktor Komitmen Kerja } & Mean (purata) \\
\hline Faktor Penyeliaan & 2.4561 \\
Faktor Rakan Sekerja & 2.3628 \\
Faktor Pendapatan & 2.4400 \\
Faktor Minat & 2.7694 \\
\hline
\end{tabular}

\section{Analisis Tahap Prestasi Kerja dalam kalangan Penjawat Awam}

Nilai minimum prestasi kerja adalah 2.25 manakala nilai maksimum pula adalah 3.92. Selain itu, nilai sisihan piawaian bagi prestasi kerja adalah 0.29164 serta nilai purata pula menunjukkan 3.0100.

Jadual 2 : Hasil Analisis Deskriptif bagi Prestasi Kerja

\begin{tabular}{ccccc}
\hline & Minimum & Maksimum & Sisihan Piawai & Purata \\
\hline Prestasi Kerja & 2.25 & 3.92 & 0.29164 & 3.0100 \\
\hline
\end{tabular}

Jadual 3: Penentuan Tahap berdasarkan Nilai Purata

\begin{tabular}{|c|c|c|c|}
\hline Skala Likert & 2 & & 3 \\
\hline Skala Likert 3 Mata & 1 & 2 & 3 \\
\hline Nilai Purata & $1.000-2.490$ & 2.500 & $2.510-4.000$ \\
\hline Tahap & Rendah & Sederhana & Tinggi \\
\hline
\end{tabular}

Berdasarkan kepada hasil analisis deskriptif yang telah dijalankan, prestasi kerja penjawat awam di KEMAS, Daerah Seberang Perai Tengah adalah berada pada tahap yang tinggi kerana nilai purata melebihi nilai 2.510 (Jadual 3). Merujuk kepada nilai minimum dan maksimum yang diperoleh, prestasi kerja yang paling rendah yang diperoleh oleh kakitangan di jabatan ini adalah pada skor 2.25 manakala prestasi kerja yang paling tinggi yang diperoleh adalah pada skor 3.92 meskipun secara keseluruhannya yang merujuk kepada nilai purata, prestasi kerja penjawat awam di jabatan ini berada pada tahap yang tinggi.

\section{Analisis Kolerasi antara Faktor-faktor Komitmen Kerja dengan Prestasi Kerja}

Analisis korelasi bagi hubungan faktor penyelia dengan prestasi kerja telah menunjukkan tiada hubungan yang signifikan dengan nilai $r=0.159$ pada aras $p<0.05$ dan $p<0.01$. 
Jadual 4 : Hasil Analisis Kolerasi Antara Faktor-faktor Komitmen

Kerja dengan Prestasi Kerja

\begin{tabular}{lcc}
\hline \multicolumn{1}{c}{ Faktor-faktor komitmen Kerja } & Kolerasi Pearson & Sig. (2-tailed) \\
\hline Faktor Penyeliaan & 0.159 & 0.115 \\
Faktor Rakan Sekerja & 0.039 & 0.699 \\
Faktor Pendapatan & 0.090 & 0.373 \\
Faktor Minat & $0.593^{* *}$ & 0.000 \\
\hline$* *$ Correlation is significant at the 0.01 level (2-tailed) &
\end{tabular}

Analisis korelasi bagi hubungan faktor rakan sekerja dengan prestasi kerja telah menunjukkan tiada hubungan yang signifikan dengan nilai $r=0.039$ pada aras $\mathrm{p}<0.05$ dan $\mathrm{p}<0.01$.

Analisis korelasi bagi hubungan faktor pendapatan dan prestasi kerja telah menunjukkan tiada hubungan yang signifikan dengan nilai $r=0.090$ pada aras $\mathrm{p}<0.05$ dan $\mathrm{p}<0.01$.

Analisis korelasi bagi hubungan faktor minat dengan prestasi kerja telah menunjukkan hubungan korelasi yang kuat dengan nilai $r=0.593$ pada aras $p<0.05$ dan $p<0.01$.

\section{Analisis perbezaan Prestasi Kerja mengikut Jantina}

Hasil analisis menunjukkan nilai purata bagi lelaki adalah 2.8958 manakali nilai purata bagi perempuan pula adalah 3.0148. Selain itu, nilai t menunjukkan nilai negatif iaitu -0.798 dan nilai $\mathrm{p}$ adalah nilai yang positif iaitu 0.427 . Merujuk pada nilai $p$, ianya menunjukkan bahawa tidak terdapat perbezaan yang signifikan bagi prestasi kerja mengikut jantina kerana nilai $\mathrm{p}$ adalah melebihi 0.05 .

Jadual 5 : Hasil Analisis Perbezaan Prestasi Kerja mengikut Jantina

\begin{tabular}{|c|c|c|c|c|}
\hline \multirow[b]{2}{*}{ Pembolehubah } & \multicolumn{2}{|c|}{ Purata } & \multirow[b]{2}{*}{$t$} & \multirow[b]{2}{*}{$p$} \\
\hline & $\begin{array}{c}\text { Lelaki } \\
(N=4)\end{array}$ & $\begin{array}{c}\text { Perempuan } \\
(\mathbf{N}=96)\end{array}$ & & \\
\hline Prestasi Kerja & 2.8958 & 3.0148 & -.798 & .427 \\
\hline
\end{tabular}

\section{Analisis Perbezaan Prestasi Kerja mengikut Tempoh Perkhidmatan}

Nilai purata bagi tempoh perkhidmatan 16 hingga 20 tahun menunjukkan nilai yang paling tinggi iaitu 3.0648 diikuti dengan tempoh perkhidmatan 21 tahun ke atas dengan nilai purata 3.0466 , tempoh perkhidmatan 6 hingga 10 tahun dengan nilai purata 2.9975, tempoh perkhidmatan 11 hingga 15 tahun dengan nilai purata 2.9653 dan akhir sekali adalah bagi tempoh perkhidmatan 5 tahun ke bawah dengan nilai purata yang paling rendah iaitu 2.9444. Selain itu, hasil analisis juga mendapati nilai $\mathrm{F}$ adalah 4.342 manakala nilai sig. $\mathrm{F}$ pula adalah 0.003 . Merujuk kepada nilai sig. $\mathrm{F}$, hal ini menunjukkan bahawa terdapat perbezaan yang signifikan antara prestasi kerja mengikut tempoh perkhidmatan kerana nilai sig. F adalah kurang daripada 0.05 .

Jadual 6: Hasil Analisis Perbezaan Prestasi Kerja mengikut Tempoh Perkhidmatan

\begin{tabular}{cccccccc}
\hline $\begin{array}{c}\text { Tempoh } \\
\text { Perkhid. } \\
(\mathbf{I})\end{array}$ & Purata & $\begin{array}{c}\text { Tempoh } \\
\text { Perkhidmatan } \\
(\mathbf{J})\end{array}$ & $\begin{array}{c}\text { Perbezaan } \\
\text { Purata } \\
(\mathbf{I}-\mathbf{J})\end{array}$ & $\begin{array}{c}\text { Std. } \\
\text { Error }\end{array}$ & Sig. & F & Sig. $\boldsymbol{F}$ \\
\hline & & $6-10$ tahun & -.05303 & .09944 & .984 & & \\
5 tahun ke & 2.9444 & $\begin{array}{c}11-15 \text { tahun } \\
\text { bawah }\end{array}$ & -.02083 & .12043 & 1.000 & & \\
& & $\begin{array}{c}16-20 \text { tahun } \\
\text { > } 21 \text { tahun }\end{array}$ & -.12037 & .13008 & .886 & 4.342 & $.003^{* *}$ \\
6 tahun & 2.9975 & $<5$ tahun & .05303 & .09905 & .840 & & \\
\hline
\end{tabular}




\begin{tabular}{|c|c|c|c|c|c|}
\hline \multirow{3}{*}{$\begin{array}{c}\text { hingga } 10 \\
\text { tahun }\end{array}$} & & $11-15$ tahun & .03220 & .09944 & .998 \\
\hline & & $16-20$ tahun & -.06734 & 11093 & .974 \\
\hline & & $>21$ tahun & -.04909 & .07209 & .960 \\
\hline \multirow{3}{*}{$\begin{array}{l}11 \text { tahun } \\
\text { hingga } 15 \\
\text { tahun }\end{array}$} & \multirow{3}{*}{2.9653} & $<5$ tahun & .02083 & .12043 & 1.000 \\
\hline & & $6-10$ tahun & -.03220 & .09944 & .998 \\
\hline & & $\begin{array}{l}16-20 \text { tahun } \\
>21 \text { tahun }\end{array}$ & $\begin{array}{l}-.09954 \\
-.08129\end{array}$ & $\begin{array}{l}.13008 \\
.09905\end{array}$ & $\begin{array}{l}.940 \\
.924\end{array}$ \\
\hline \multirow{5}{*}{$\begin{array}{c}16 \text { tahun } \\
\text { hingga } 20 \\
\text { tahun }\end{array}$} & \multirow{4}{*}{3.0648} & $<5$ tahun & .12037 & .13008 & .886 \\
\hline & & $6-10$ tahun & .06734 & .11093 & .974 \\
\hline & & $11-15$ tahun & .09954 & .13008 & .940 \\
\hline & & $>21$ tahun & .01825 & .11058 & 1.000 \\
\hline & \multirow{4}{*}{3.0466} & $<5$ tahun & 10212 & .09905 & .840 \\
\hline \multirow{3}{*}{$\begin{array}{l}21 \text { tahun } \\
\text { ke atas }\end{array}$} & & $6-10$ tahun & .04909 & .07209 & .960 \\
\hline & & $11-15$ tahun & .08129 & .09905 & .924 \\
\hline & & $16-20$ tahun & -.01825 & .11058 & 1.000 \\
\hline
\end{tabular}

**. The level of significant is at sig. $F(p)<0.05$

\section{Kesimpulan}

Hasil kajian mendapati bahawa faktor komitmen kerja utama yang mempengaruhi prestasi kerja dalam kalangan penjawat awam di Jabatan Kemajuan Masyarakat (KEMAS) Negeri Pulau Pinang, Daerah Seberang Perai Tengah adalah faktor minat Hal ini disokong dengan terdapat perhubungan antara faktor minat dengan prestasi kerja yang menunjukkan hubungan korelasi yang kuat dengan nilai $\mathrm{r}=0.593$ pada aras $\mathrm{p}<0.05$.

Berdasarkan kepada borang soal selidik yang dikemukakan, penyelidik mendapati bahawa kakitangan di jabatan ini menganggap pekerjaan mereka adalah pekerjaan yang baik, dihormati dan berguna kepada masyarakat. Mereka amat berpuas hati dengan kerjaya yang mereka miliki kerana ianya dapat memberi pencapaian dan ganjaran buat diri mereka sendiri. Mereka juga merasakan pekerjaan mereka menyeronokkan dan mempesonakan sehingga dapat melihat hasil daripada pekerjaan tersebut. Hal ini membuktikan minat kakitangan ini yang mendalam terhadap pekerjaan mereka kerana majoriti daripada mereka melihat pekerjaan ini daripada aspek yang positif.

Faktor minat amat mempengaruhi prestasi kerja dalam kajian ini kerana tunjang utama jabatan ini adalah dalam sektor pendidikan terhadap kanak-kanak di Tabika KEMAS. Oleh itu, apabila seseorang itu mempunyai minat terhadap kanak-kanak ataupun minat terhadap kerjaya perguruan, maka proses pembelajaran dan pengajaran menjadi lebih mudah dan berkesan. Dalam kajian Halimah (2006) mendapati bahawa faktor intrinsik yang paling popular dalam kalangan wanita bagi memilih kerjaya perguruan adalah faktor sukakan kanak-kanak. Tuntasnya dalam kajian ini, faktor minat ini memberi hasil kepada prestasi kerja mereka yang baik dan secara tidak langsung memberi kesan kepada kualiti penyampaian pengajaran yang baik dimana bertepatan dengan laporan dalam keratan akhbar Kosmo bertarikh 21 September 2016 yang bertajuk "Tabika KEMAS miliki kualiti tinggi". Ternyata faktor penyelia, pendapatan dan rakan sekerja tidak menjadi penghalang kepada kakitangan di jabatan ini untuk memberi perkhidmatan yang terbaik jika mereka telah mempunyai minat yang mendalam terhadap pekerjaan yang dilakukan.

Bagi analisis perbezaan prestasi kerja mengikut jantina dan tempoh perkhidmatan, dapatan kajian menunjukkan perbezaan yang signifikan antara prestasi kerja mengikut tempoh perkhidmatan. Pekerja yang telah lama berkhidmat mempunyai pengalaman yang lebih luas. Oleh itu, mereka mungkin tidak memerlukan masa yang lama untuk membuat keputusan dan menyelesaikan sesuatu tugasan. Masyitah dan Zawiyah (2005) pula menyatakan bahawa pekerja yang telah lama berkhidmat memberi reaksi yang lebih positif tentang persekitaran tempat kerja kerana mempunyai pengalaman dan selok-belok pekerjaan yang dilakukan berbanding pekerja baru. Oleh itu, hal ini secara tidak langsung memberi kesan kepada kualiti perkhidmatan mereka yang berkesan seterusnya prestasi kerja mereka yang baik. Tambahan pula, jika dilihat pada hasil analisis kajian, nilai purata tertinggi adalah pada tempoh 
perkhidmatan 21 tahun ke atas. Penyelidik menyimpulkan bahawa kakitangan yang telah lama bekerja cenderung untuk lebih gigih dalam melaksanakan pekerjaan mereka kerana berasa selesa dengan pendapatan dan pampasan yang diterima. Hal ini turut disokong oleh hasil kajian daripada Byrd dan Cooperman (2010) dimana tempoh perkhidmatan bagi CEO yang setia dan lama berkhidmat menunjukkan hubungan yang positif dengan prestasi dan pampasan yang akan diperoleh dan akan melakukan khidmat dengan lebih jika pampasan yang diperoleh setimpal dengan usaha dan kesetiaan yang diberikan. Tuntasnya, pihak organisasi perlu mengeluarkan inisiatif untuk memupuk minat pekerja terhadap pekerjaan yang mereka lakukan agar setia dan ikhlas melakukan kerja.

\section{Rujukan}

Bendix, C. (1956). Work and Authority in Industry. New York: Wiles.

Byrd, J., \& Cooperman, E. S. (2010). Director tenure and the compensation of bank CEOs. Managerial Finance, 36 (2) 86-102.

Che Mohd Syaharuddin Che Cob, Bahyah Abdul Halim dan Aziz Amin (2017).Faktor-faktor yang mempengaruhi Prestasi Kerja dalam kalangan Penjawat Awam: Satu Kajian Teoritikal. Jurnal Sultan Alauddin Sulaiman Shah, Bol. 4, Bil. 1 (2017), e-ISSN: 2289-8049. https://docplayer.net/54989314-Faktor-faktor-yang-mempengaruhi-prestasi-kerja-dalamkalangan-penjawat-awam-satu-kajian-teoritikal.html

Cole, A. L. (1991). Relationship in the Work Place: Doing What Comes Naturally. Teaching and Teacher Education, 7, 415-126.

Conrad, C. (1985). Strategic Organizational Communication, Cultures, Situation and Adaptation. New York: CBS College Publishing.

Dalyono. 1997. Psikologi Pendidikan. (Jakarta: Rineka Cipta).

Farrel, E., (2003). Patterns of leadership behavior related to employee grievances and turnover. Personal Psychology, 15, 43-56.

Glickman, C. D., Gordon, S. P., \& Gordon, J. M. (1995). Supervision of instruction: A developmental approach (3rd ed.). Boston: Allyn \& Bacon.

Goldthorpe, J. H. (1968). Organizational Intelligence: Knowledge and Policy in Government and Industry. British Journal of Sociology, 19(2), 225.

Hillgard, E. (1995). Theories of Learning. New York: Appleton

Hodson, Randy and Teresa A. Sullivan (1995) The Social Organization of Work, 2nd edn. Belmont, CA: Wadsworth.

Jordell, K. (1987). Structural and Personal Influences in the Socialization of Beginning Teachers. Teaching and Teacher Education, 3(3), 165-177.

Morgan, F. (1978). Sales Persons' and Managers' Perceptions of Work Environment and Job Performance. Industrial Marketing Management, 7, 170-177.

Mottaz, C. (1988). An Analysis of the relationship between attitudinal commitment and behavioral commitment. Socialogy Quarterly, 30, 143-158.

Noel, T. W. (2009). The Impact of Knowledge Resource on New Venture Performance. Journal of Small Business Management, 47 (1), 1-22.

N.a. (22 November 2010). 6,133 penjawat awam bermasalah. Utusan Online. Diambil pada Ogos 10, 2018 daripada http://ww1.utusan.com.my/utusan/info.asp?y=2010\&dt=1122\&pub=Utusan Malaysia\&sec $=$ Terkini\&pg=bt_17.htm

N.a. (03 Disember 2015). CUEPACS sokong penjawat awam dinilai prestasi kerja. Utusan online. Diambil pada Ogos 10, 2018 daripada http://www.utusan.com.my/berita/nasional/cuepacssokong-penjawat-awam-dinilai-prestasi-kerja-1.165152

N.a. (18 April 2012). Penjawat awam perlu tingkat prestasi kerja. Sinar online. Diambil pada daripada http://www.sinarharian.com.my/nasional/penjawat-awam-perlu-tingkat-prestasi-kerja-1.40994

N.a. N.d. Pengurusan Prestasi. Diambil pada Jun 27, 2019 daripada https://www.jpa.gov.my/index.php?option=com_content\&view=article\&id=100\&Itemid=1978\&1 ang $=\mathrm{ms}$

Noralai Ismail dan Norhasni Zainal Abidin (2010).Tinjauan Faktor-faktor yang mempengaruhi Komitmen Pekerja terhadap Organisasi. Dinamika Sosial Ekonomi, Volume 6, No. 1Mei 2010. http://www.kopertis6.or.id/journal/index.php/sosek/article/view/8/8 
Pekeliling Kemajuan Pentadbiran Awam, Bilangan 2. 2005. Garis panduan bagi mewujudkan petunjuk-petunjuk prestasi utama atau key performance indicators (KPI) dan melaksanakan pengukuran prestasi di agensi kerajaan. Jabatan Perdana Menteri Malaysia.

Rambli Haji Hasbi (2001). Perkaitan Kepuasan Kerja dengan PrestasiKerja di kalangan Pekerja di Industri Pembuatan. Fakulti Sains Kognitif dan Pembangunan Manusia, Universiti Malaysia Sarawak.https://ir.unimas.my/id/eprint/3758/1/Perkaitan\%20kepuasan\%20kerja\%20dengan\%20pr estasi\%20kerja\%20di\%20kalangan\%20pekerja\%20di\%20industri\%20pembuatan.pdf

Sardiman. A.M, (2000). Interaksi \& Motivasi Belajar Mengajar. Jakarta: Rajawali Pers.

Zeichner, K. (1983). Individual and Institutional Factors Related to The Socialization of Beginning teachers. Teaching and Teacher Education, 3(3), 165-177. 